IFAS Extension

\title{
Florida Cow-Calf and Stocker Beef Safety and Quality Assurance Handbook: Record Keeping for Beef Quality Assurance ${ }^{1}$
}

\author{
Todd A Thrift, Matt J. Hersom and Max Irsik ${ }^{2}$
}

1. This document is AN172, one of a series of the Animal Science Department, Florida Cooperative Extension Service, Institute of Food and Agricultural Sciences, University of Florida. Original publication date October 2006. Reviewed November 2009. Visit the EDIS Web Site at http://edis.ifas.ufl.edu.

2. Todd Thrift, Assistant Professor, and Matt J. Hersom, Assistant Professor, UF Department of Animal Sciences; Max Irsik, Assistant Professor, College of Veterinary Medicine; Institute of Food and Agricultural Sciences, University of Florida, Gainesville, 32611. 


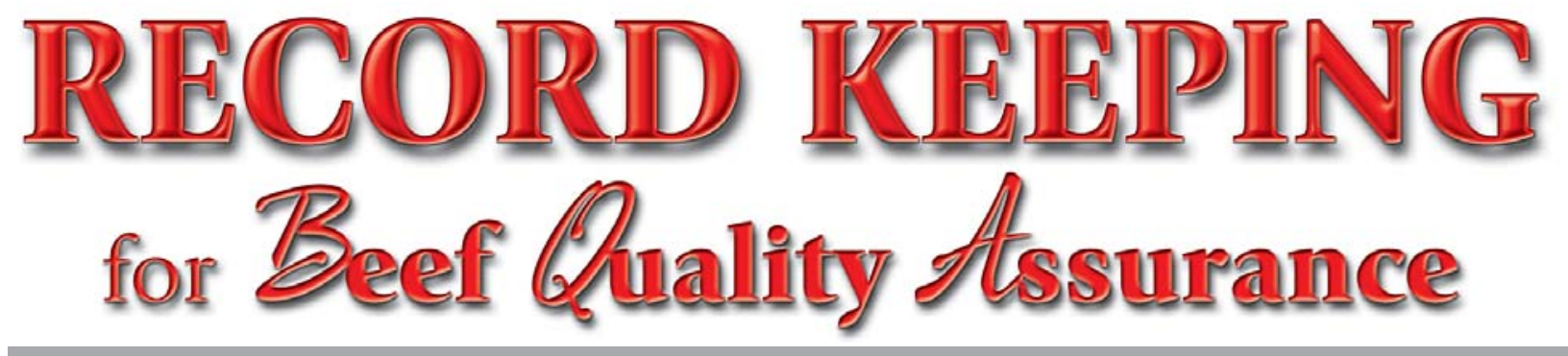

\section{Why keep records?}

Record keeping is a key element of Beef Quality Assurance, and it's simply a good business practice. There are many software programs on the market that are designed for both commercial and purebred cattle operations. However, even old-fashioned pen and paper is still an acceptable record keeping system.

The important thing is to find a method that you are comfortable with, which allows you to maintain accurate, thorough and timely documentation of your herd health program, nutrition program and other important production factors. It's also essential to controlling your costs of production and keeping your eye on other pieces of data that help you make informed management decisions.

For example, animal health records tell the manager and veterinarian what treatments are being used so they can make sure that recommendations are being followed and decide whether treatment protocols need to be adjusted.

As well, to inspire consumer confidence we must be able to document the responsible use of products and demonstrate that we have control over risk factors that have residue potential. Good records are also important if your operation is inspected (for example, if one of your cull cows is found to have a violative residue) by any state or federal agency.

Should your operation get cited for a residue violation and you believe it's a case of mistaken identity, good records are your only evidence that the animal in question does not belong to you. Or, if it is your animal, then your records may prove the animal was never given the particular drug in question.

Effective documentation showing appropriate training, inventory control, product use, animal identification, withdrawal and disposal is the only way to avoid liability from a residue contamination. The only way to accurately determine if you are in compliance with withdrawal times is to know exactly what was given, how much was given, where it was given, how it was given and when it was given to the animal.

Updated records also allow you to make well-informed decisions about marketing cattle without worrying whether enough time has elapsed since the last treatment. Also, as mentioned in the section on feed contamination, you should keep records on your use of pesticides, herbicides and other chemicals. Understand the remarks and safety restrictions with regard to withdrawal times and animal types (pregnant, lactating, etc.) that should not be treated or exposed to treated areas. 


\section{Best Management Practices - Animal Treatment Records}

1. Keep all records for at least two years from the date of transfer or sale of the cattle. In case a problem arises later, your records will help you track the treatment history of the animal when it was in your possession.

2. The treatment record should contain the following information:

a) Treatment date,

b) Diagnosis

c) Animal or group identification

d) Approximate weight of animal or group average

e) Product administered

f) Product lot/serial number

g) Earliest date the animal could clear withdrawal time

h) Dose given

i) Route of administration (IM, SQ, etc.)

j) Location of injections

k) Name of person who administered the drug

3. A copy of the appropriate records should be made available to the buyer of your cattle or as they are transferred from one unit of your ranch to another. Records should include all individual and group treatment/processing history and other information as deemed appropriate.

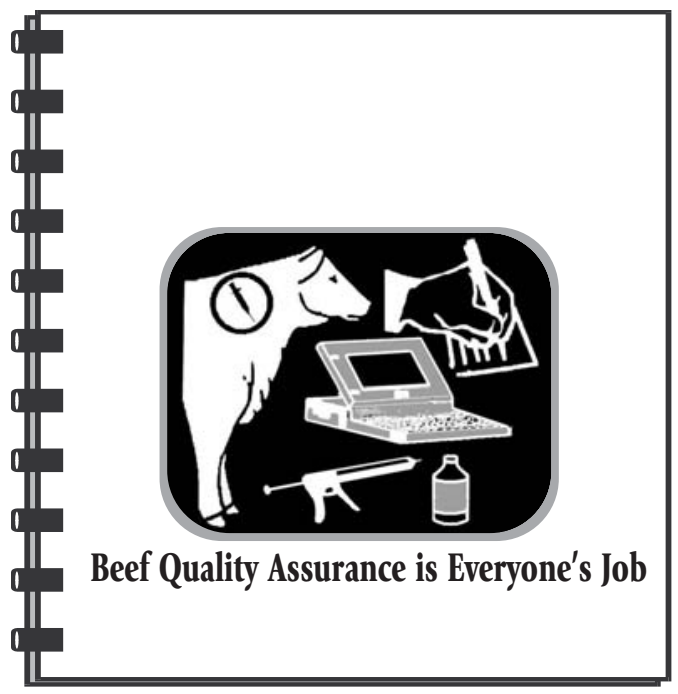


The sample records provided here give you an idea of how to record information on each animal health product you purchase, as well as an example of an individual animal treatment record and a group treatment record. There are also full-page sample forms in the Appendix, which can be copied or easily reproduced on your computer.

\section{Animal Health Products Inventory}

\begin{tabular}{|c|l|l|l|l|l|l|}
\hline $\begin{array}{c}\text { Date } \\
\text { Received }\end{array}$ & Supplier/Distributor & Product Name & Quantity & Cost & $\begin{array}{l}\text { Lot or } \\
\text { Serial \# }\end{array}$ & $\begin{array}{l}\text { Expiration } \\
\text { Date }\end{array}$ \\
\hline & & & & & & \\
\hline & & & & & & \\
\hline & & & & & & \\
\hline
\end{tabular}

\section{Individual Animal Health Record}

\begin{tabular}{|c|c|c|c|c|c|c|c|c|c|c|c|}
\hline I.D. & Date & Weight & $\begin{array}{c}\text { Product } \\
\text { Temp. }\end{array}$ & $\begin{array}{c}\text { Lot or } \\
\text { Diagnosis }\end{array}$ & Treatment & Serial \# & ROA* & Dose & $\begin{array}{c}\text { Treatment } \\
\text { Location }\end{array}$ & $\begin{array}{c}\text { Date of } \\
\text { Withdrawal }\end{array}$ & $\begin{array}{l}\text { Initials of } \\
\text { Processor }\end{array}$ \\
\hline & & & & & & & & & & & \\
\hline \\
\hline
\end{tabular}




\section{GROUP PROCESSING/TREATMENT MAP}

Name/Ranch

Address

City

Group/Description:

Processint Date:

Class: S / H / Bulls / Cows

Other Management: Castrate

Booster/Reprocess Date:

When possible select SQ products and never give injection in the rear leg or top butt. Indicate site of treatment with the corresponding \# from table.
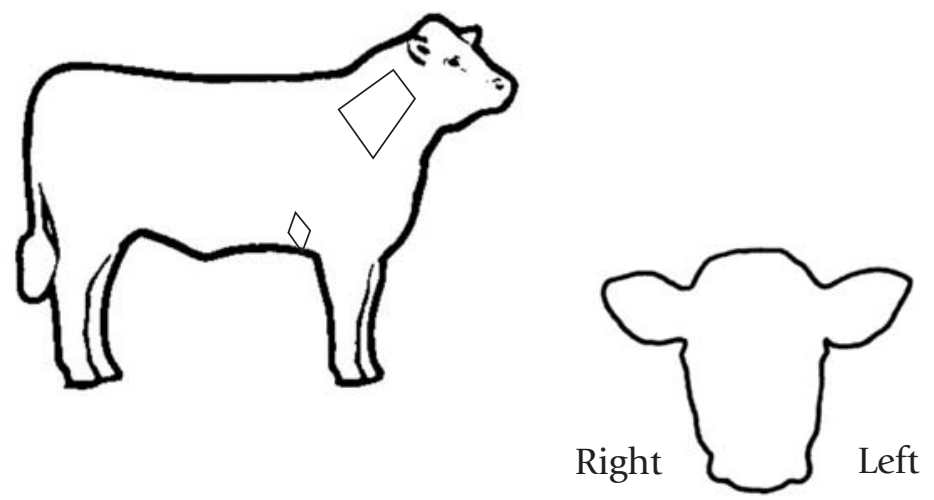

Premise \#

Phone \#

State

Zip

ID/Brand:

Calving Season Date: Pen/Pasture \#:

Weight: Hd processed:

Dehorn Other Crew: 


\section{Best Management Practices -Feed Records}

1. Keep all feed records for at least two years (an industry standard) from the date of transfer or sale of the cattle. In case of a problem, you will have documents to prove what you have or have not fed your cattle.

2. It's a good management practice to require that all feed products be accompanied by an invoice that includes the date, amount, lot/batch number and signatures of both the person who delivered the product and the person receiving the product.

\section{Best Management Practices - Chemical Records}

1. If you are a licensed pesticide applicator (required to purchase restricted-use chemicals), the Florida Department of Agriculture and Consumer Services already requires you to keep records on your use of these chemicals. These records are sufficient to meet BQA guidelines. (Full-page forms such as below can be found in the Appendix.)

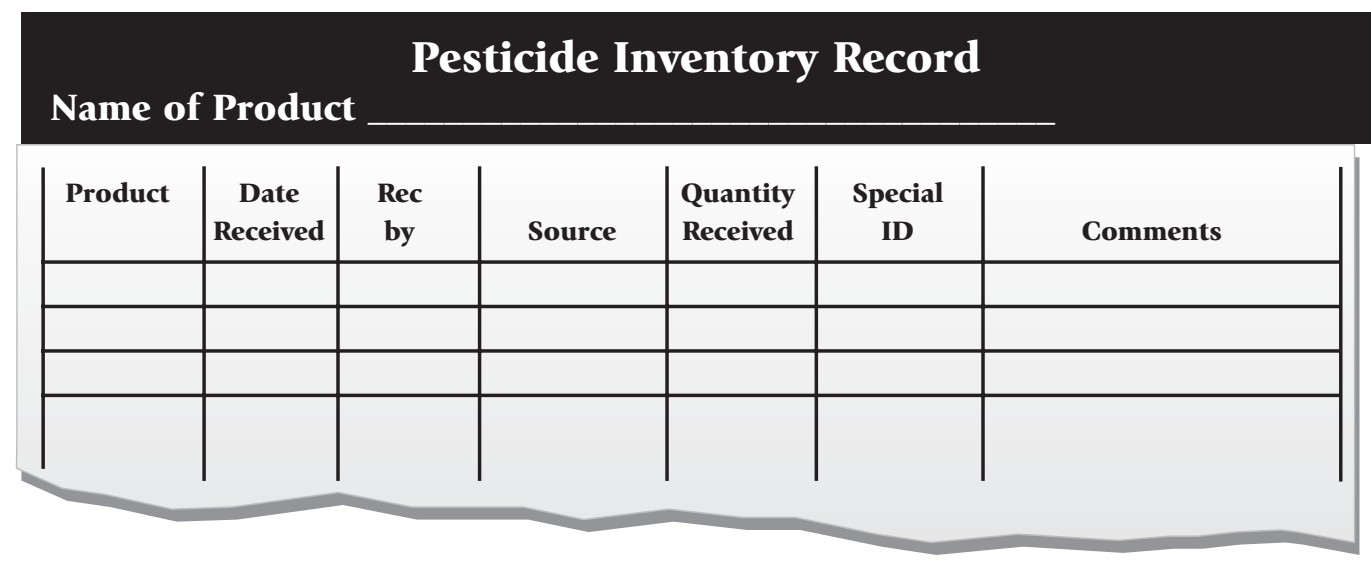

\section{Pesticide Use Record}

PR=Pesticide name, WD=Withdrawal time

\begin{tabular}{|l|l|l|l|l|l|l|l|l|l|l|l|}
\hline $\begin{array}{l}\text { Date and } \\
\text { Time of } \\
\text { Treatment }\end{array}$ & $\begin{array}{l}\text { Actual } \\
\text { Applicator } \\
\text { if different } \\
\text { from above) }\end{array}$ & $\begin{array}{l}\text { Application } \\
\text { Method }\end{array}$ & $\begin{array}{l}\text { Brand } \\
\text { Name }\end{array}$ & $\begin{array}{l}\text { Active } \\
\text { Ingredient }\end{array}$ & $\begin{array}{l}\text { Product EPA } \\
\text { Registration \# } \#\end{array}$ & $\begin{array}{l}\text { Crop } \\
\text { Treated }\end{array}$ & $\begin{array}{l}\text { Rate } \\
\text { Applied per } \\
\text { Acre }\end{array}$ & $\begin{array}{l}\text { Size of } \\
\text { Area } \\
\text { Treated }\end{array}$ & $\begin{array}{l}\text { Total } \\
\text { Amount } \\
\text { Applied }\end{array}$ & $\begin{array}{l}\text { Restricted } \\
\text { Entry } \\
\text { Interval }\end{array}$ & $\begin{array}{l}\text { Grazing or } \\
\text { Hay } \\
\text { Restricted }\end{array}$ \\
\hline & & & & & & & & & & & \\
\hline \\
\hline
\end{tabular}




\section{Pesticide Record Keeping Requirements of Four State and Federal Laws}

\begin{tabular}{|c|c|c|c|c|}
\hline RECORD & RTK & FL & FACT & WPS \\
\hline Date & Required & Required & Required & Required \\
\hline Time (Start \& end) & Required & Required & & Required \\
\hline Product (Brand name) & Required & Required & Required & Required \\
\hline Active Ingredients & Required & & & Required \\
\hline EPA No. & Required & Required & Required & Required \\
\hline Crop & & Required & Required & \\
\hline Acres treated & & Required & Required & \\
\hline Re-entry interval & & & & Required \\
\hline Total mix applied & & Required & Required & \\
\hline Application Method & & Required & & \\
\hline \multicolumn{5}{|l|}{ Wind direction } \\
\hline \multicolumn{5}{|l|}{ Wind speed } \\
\hline \multicolumn{5}{|l|}{ Temperature } \\
\hline Location & Required & Required & & Required \\
\hline Crop owner & & Required & & \\
\hline Applicator & & Required & Required & \\
\hline App. License No. & & Required & Required & \\
\hline Application to record & Current & Current & & Before treating \\
\hline Record storage & 30 years & 2 years & 14 days & 30 days \\
\hline
\end{tabular}

RTK - Right to Know

FL - Florida Law

FACT - Food Agriculture Conservation Trade

WPS - Worker Protection Standard 